\title{
Health care waste management among health workers and associated factors in primary health care facilities in Kampala City, Uganda: a cross-sectional study
}

\author{
Solomon Tsebeni Wafula ${ }^{1 *}$ (D), Julian Musiime ${ }^{2}$ and Frederick Oporia ${ }^{1}$
}

\begin{abstract}
Background: Healthcare wastes (HCWs) are one of the most hazardous wastes globally; second to only radiation waste. HCW management needs to be prioritized because of the devastating effects on human health and environment if not well managed. Health workers play a crucial role in management of HCWs. This study investigated the management of HCWs among health workers and associated factors in primary health care facilities in Kampala City, Uganda.

Methods: We conducted a cross-sectional health facility survey in 8 primary health care facilities in Kampala City from March to April 2017. We interviewed health workers who provided data on socio-demographic characteristics, knowledge, attitudes and practices on HCW management. Prevalence ratios (PRs) and their corresponding 95\% confidence intervals were used as a measure of association between HCW management and associated factors. The PRs were obtained using a multivariable modified Poisson regression using a generalized linear model of Poisson family with a logarithm as the canonical link function, with robust standard errors while applying a forward elimination method.
\end{abstract}

Results: A total of 200 health workers responded to the survey; Knowledge of HCW management was high 143 (71.5\%, 95\% Cl (65.2-77.8)). About 160 (80.0\%) wore appropriate personal protective wear when handling HCWs. Overall, 148 (74.0\%, 95\% Cl (67.8-80.1) had satisfactory HCW management practices. Health workers with diploma education (Adjusted PR $=1.49,95 \% \mathrm{Cl}(1.13-1.96)$, working in the teenage corner (Adjusted PR $=1.10,95 \% \mathrm{Cl}(1.01-$ 1.29), previous training on $\mathrm{HCW}$ management (Adjusted $\mathrm{PR}=1.19,95 \% \mathrm{Cl}(1.01-1.42)$ and those who thought HCW management was important (Adjusted PR $=2.81,95 \% \mathrm{Cl}(1.22-6.47)$ were more likely to have satisfactory HCW management practices.

Conclusion: The practices of health workers on HCW management were largely satisfactory. Higher odds of HCW management were determined among health workers with diploma education, previous HCW management trainings and among those who perceived HCW management as important. There is need to organize HCW management trainings in order to improve their HCW management practices among health workers.

Keywords: Healthcare waste, Waste management, Healthcare workers, Primary health care facilities, Kampala, Uganda

\footnotetext{
* Correspondence: swafula@musph.ac.ug

${ }^{1}$ Department of Disease Control and Environmental Health, School of Public

Health, Makerere University, P.o Box 7072, Kampala, Uganda

Full list of author information is available at the end of the article
}

(c) The Author(s). 2019 Open Access This article is distributed under the terms of the Creative Commons Attribution 4.0 International License (http://creativecommons.org/licenses/by/4.0/), which permits unrestricted use, distribution, and reproduction in any medium, provided you give appropriate credit to the original author(s) and the source, provide a link to the Creative Commons license, and indicate if changes were made. The Creative Commons Public Domain Dedication waiver (http://creativecommons.org/publicdomain/zero/1.0/) applies to the data made available in this article, unless otherwise stated. 


\section{Background}

Health care wastes are considered the second most hazardous wastes globally after radiation waste [1]. Healthcare wastes encompasses various forms of waste such as sharps, human body parts, blood, chemical wastes, pharmaceutical wastes, and medical devices [2]. These wastes are majorly generated from hospitals and primary care facilities, laboratories, mortuaries, autopsy centres, laboratories, blood banks, nursing homes among others [3]. Healthcare wastes can have devastating effects on human health if not properly handled [4]. Mismanagement of HCWs can result into various hospital-acquired infections, occupational health hazards and food contamination [5]. In addition, mismanaged wastes such as sharps contaminated with blood facilitates transmission of infections such as hepatitis B, hepatitis C, HIV/AIDs and other viral infections $[2,6,7]$. Health care workers, patients, workers in support services, visitors to health facilities, waste handlers, scavengers, fetuses in the wombs, and the general public are susceptible to these infections $[2,8]$.

In developing countries especially in Africa, healthcare waste has not received the much needed attention that it deserves [9-11]. This is because of the inadequate resources in these countries resulting into low priority for $\mathrm{HCW}$ management [12]. In many countries, there is limited segregation of hazardous and medical wastes and usually mixed with non-infectious waste [13, 14]. Inadequate knowledge and unsatisfactory management practices among the health care workers are major challenges in the management of HCWs [15]. Previous research indicate that $\mathrm{HCW}$ management may be affected by lack of formal training, lack of knowledge on HCW management, limited interest from hospital administration [16-18].

In Uganda, the HCW generated is averaged at 92 Kilograms $(\mathrm{Kg})$ per day in hospital while primary health care facilities (Level IV health centers, level III health Centre and level II Health Centre) generate about $42 \mathrm{Kg}, 25 \mathrm{~kg}$ and $20 \mathrm{~kg}$ respectively on daily basis [19]. Moreover, most of these primary health care facilities lack proper HCW management facilities [20, 21]. Despite the policy guidelines on injection and HCW management developed by the Ministry of Health, Uganda, there is sufficient evidence that HCWs including in Kampala health facilities is not properly handled [22, 23]. Although health care workers are routinely involved in managing $\mathrm{HCW}$ at their workstations, there is little published data on HCW management among health workers and more especially in primary health care facilities. Previous studies $[16,23,24]$ on HCW management in East Africa were mainly conducted in high level health facilities (hospitals) and not primary health care facilities. These studies also delved more on HCW at facility management level and did not explore HCW management among health workers. There is paucity of studies conducted to assess the management of HCWs among health workers in primary health care facilities and factors that may influence it.

We therefore set out to understand HCW management practices among health workers in primary health care facilities in Kampala and the factors that influence those practices.

\section{Methods}

\section{Study design, setting and study population}

The study was cross sectional in design and employed quantitative techniques of data collection. It was conducted in Kampala, Uganda's Capital City between March to April 2017. According to 2014 census results, Kampala has an estimated resident population of 1,507,080 people with an annual growth rate of $2.02 \%$ [25].

This study was conducted among health workers in 8 primary health care facilities in Kampala. In Uganda, the health care system is organised into a four-tier system (i.e., hospitals, health centres of levels IV, III and II). Hospitals are considered high level facilities while health centres; II, III and IV are lower level and are classified as primary health care facilities. These primary health care facilities offer basic services for example Health centre IIs offer out-patients consultations, health centre IIIs offer inpatient care and some laboratory services. In addition to services offered at lower levels, Health centre of level IV offer some caesarean operations and blood transfusion services. The main waste streams generated in these facilities included sharps, pathological wastes, infectious wastes and general wastes.

The study units were the primary health care facilities and the study participants were health workers. In this study, we defined a health worker as a person who works at health care centre and is engaged in all actions aimed primarily on enhancing health of patients. These health workers included nurses, midwives, medical officers, laboratory personnel, counsellors and social workers. All selected health workers who consented were interviewed. Those who were absent on leave or medically not well were excluded.

\section{Sample size and sampling procedure}

The Kish Leslie formula for cross sectional studies was used to calculate sample size of 231 health workers [26].

$$
\text { Sample size, }(\mathrm{N})=\frac{\mathrm{Z} \alpha^{2} \mathrm{pq}}{\sigma^{2}}
$$

We considered, the following assumptions: $\mathrm{Z}$ score, $Z \alpha=1.96$; prevalence, $p=16.3 \%$ (adopted from a study on adherence to waste disposal guidelines among health 
workers in Kenya) [27], a precision, $\sigma=5 \%$ and non-response rate of $10 \%$. It is important to note that actual population of health workers in these primary health care facilities in Kampala was small $(<500)$.

Proportionate sampling was done to select a specific number of health workers from each of the 8 primary health care facilities based on the number of health workers in each health facility (Table 1). This was based on the numbers of health workers obtained from Kampala Capital City Authority (KCCA).

From each of the health facilities, stratified proportionate sampling was again employed to select the different cadres of health workers (nurses, midwives, medical officers, laboratory personnel, counsellors and social workers).

\section{Data collection}

We used a semi-structured questionnaire to collect quantitative data from health workers on socio-demographic characteristics, knowledge of $\mathrm{HCW}$ and perceptions of risk due to $\mathrm{HCW}$ and to capture health workers' HCW management practices such as segregation, availability of necessary accessories, occupational safety and health in their work stations. The tools were developed based on findings from published studies $[1,9,23]$. We pretested data collection tools with 15 health workers in a health centre in the neighbouring Wakiso district. Pretesting was done to mitigate any errors and avoid ambiguity in preparation for actual data collection. This facility was chosen because it is close to Kampala and has similar HCW challenges as the primary health care facilities in Kampala.

\section{Data management and analysis}

Data were checked daily for completeness, entered using EpiData version 3.02 (EpiData association, Denmark). We used Stata 14.0 (Statacorp Texas; USA) for cleaning and analysis. To determine the status of HCW management (Outcome variable), which was classified as either satisfactory or unsatisfactory, seven questions were asked on practices on healthcare waste management with the responses "Yes and No". "No" was assigned 0 and "Yes" was assigned 1 . We used mean scores to divide the $\mathrm{HCW}$ management status of health workers into two groups as suggested in the SAGE encyclopaedia of communication research methods [28]. As such, respondents who scored above 4.995 (average score) on 7 questions were considered as having satisfactory healthcare waste maintenance practices and those that scored less than 4.995 were deemed not to have satisfactory healthcare waste management practices. Prevalence rate ratios (PRs) were computed using a generalized linear model of the Poisson family with the logarithm as the canonical link function, with robust standard errors while applying a forward elimination method. This was done to measure the association between the outcome and independent variables. Prevalence rate ratios (PRs) were used instead of odds ratios since the prevalence of the outcome variable was $>10 \%$, yet logistic regression's odds ratios tend to overestimate the relative risk in such instances [29, 30]. Simple models consisting of the outcome and one independent variable were run to obtain the crude PRs. In the multivariable model, variables that were significant at simple models $(p<0.05)$ and those that had plausibility with the outcome were included. The crude and the adjusted PRs and their corresponding 95\% confidence intervals were presented. Level of knowledge which was a predictor variable was also classified as either good knowledge or poor knowledge, five questions were asked on knowledge on healthcare waste management with the responses "Yes and No". "No" was assigned 0 and "Yes" was assigned 1 . Respondents who scored above 4.6 (average score) were considered as having a good knowledge and those that scored less than 4.6 were deemed to have poor knowledge on $\mathrm{HCW}$ management. Level of knowledge was however excluded in the final regression model due to collinearity. Strengthening the reporting of observational studies in epidemiology (STROBE) guidelines informed the reporting of our study [31].

Table 1 Number of health workers planned for interview at each facility

\begin{tabular}{llll}
\hline & Health facility & Number of health workers $(n)$ & Percentage (\%) \\
\hline 1 & Kisenyi Health centre & 45 & 19.5 \\
3 & Bukoto Health Centre & 12 & 5.2 \\
4 & Kawaala health centre & 36 & 15.6 \\
5 & Kisswa health centre & 40 & 17.3 \\
6 & Komamboga health centre & 22 & 9.5 \\
7 & Kitebi health centre & 25 & 10.8 \\
8 & Kisuggu health centre & 41 & 17.7 \\
& City hall clinic & 10 & 4.3 \\
\hline
\end{tabular}




\section{Results}

Socio-demographic characteristics of participants

A total of 200 health workers participated in the study representing response rate of $86.6 \%$. Participation was skewed towards the female health workers since only 53(26.5\%) were males. Two-thirds were married 135 (67.5\%), aged 18-35 years 131 (67.2\%). Most participants identified themselves as Christians 161 (80.5\%), 151 $(75.5 \%)$ as nurses or midwives by training and 136 (68.0\%) held a diploma as their highest education level (Table 2).

\section{Knowledge and attitudes of health workers on HCW management}

Knowledge of health workers on HCW management was high 143 (71.5\%). Majority knew the risks associated

Table 2 Socio-demographic characteristics of 200 health workers

\begin{tabular}{|c|c|c|}
\hline Variables & $\begin{array}{l}\text { Frequency } \\
(n=200)\end{array}$ & $\begin{array}{l}\text { Percentage } \\
(\%)\end{array}$ \\
\hline Total & 200 & 100 \\
\hline \multicolumn{3}{|l|}{ Gender } \\
\hline Female & 147 & 73.5 \\
\hline Male & 53 & 26.5 \\
\hline \multicolumn{3}{|l|}{ Age (Years) } \\
\hline $18-35$ & 131 & 65.5 \\
\hline$>35$ & 69 & 34.5 \\
\hline \multicolumn{3}{|l|}{ Marital status } \\
\hline Married & 135 & 67.5 \\
\hline Unmarried & 65 & 32.5 \\
\hline \multicolumn{3}{|l|}{ Religion } \\
\hline Christian & 161 & 80.5 \\
\hline Non-Christian & 39 & 19.5 \\
\hline \multicolumn{3}{|l|}{ Job designation } \\
\hline Nurse/midwife & 151 & 75.5 \\
\hline Medical officer & 16 & 8.0 \\
\hline Counsellor & 18 & 9.0 \\
\hline Others $^{a}$ & 15 & 7.5 \\
\hline \multicolumn{3}{|l|}{ Department } \\
\hline Outpatient department & 124 & 62.0 \\
\hline Maternity ward & 39 & 19.5 \\
\hline HIV section & 10 & 5.0 \\
\hline Teenage Corner & 10 & 5.0 \\
\hline Other departments & 17 & 8.5 \\
\hline \multicolumn{3}{|l|}{ Level of education } \\
\hline Diploma & 136 & 68.0 \\
\hline Higher secondary ( $A^{\prime}$ level) & 34 & 17.0 \\
\hline Lower secondary (O' level) & 30 & 15.0 \\
\hline
\end{tabular}

${ }^{\mathrm{a}}$ Other designations included laboratory personnel, social work with HCWs 182(91.0\%), the right colour codes for the bins for different wastes forms 179 (89.5\%). About 120 health workers (60.0\%) had been trained on HCW management and 41 (34.2\%) had attended at least three trainings. As regards attitudes, most 181 (90.5\%) indicated that HCW management was important and 186 (93.0\%) agreed that strict implementation was necessary for proper HCW Management in health facility setting (Table 3).

\section{Experiences and practices on HCW management}

Overall, most 188 (94.0\%) health workers had a waste bin around their working area and $144(72.0 \%)$ wore appropriate personal protective equipment. Only 56 (28.0\%) reported ever being affected by effects of poor HCW management with needle pricks 69.6\% (39/56) and infections $26.8 \%(15 / 56)$ being the most reported effects / accidents. Nearly three quarters 148 (74.0\%) were categorized as having satisfactory HCW management practices (Table 4).

\section{Independent predictors for HCW management among health workers}

Compared to health workers with higher secondary education, health workers with a diploma were 1.49 times more likely to have satisfactory waste management practices (Adjusted $\mathrm{PR}=1.49$, 95\%CI (1.13-1.96)), $p$ value $=0.005)$. The odds of satisfactory waste management practices were 1.1 times higher among health workers in teenage corner as compared to those working in the outpatient clinic (Adjusted PR $=1.10,95 \% \mathrm{CI}$ (1.01-1.29)), $p$ value 0.043). Participants who had been trained on HCW management were 1.19 times more likely to have satisfactory HCW management practices compared to those who had not received the training (Adjusted $\mathrm{PR}=1.19,95 \% \mathrm{CI}(1.01-1.42))$, $p$ value = 0.042). Those who considered HCW management as important were 2.81 times more likely to observe satisfactory $\mathrm{HCW}$ management practices as compared to those who thought otherwise (Adjusted PR $=2.81$, 95\%CI $(1.22-6.47)), p$ value $=0.016)$ (Table 5).

\section{Discussion}

This study aimed at understanding management of HCWs and associated factors among health workers in primary health care facilities in Kampala, Uganda. Our findings show that majority of the health workers had high knowledge on HCW management; knew how wastes are segregated and the risk to health. Most of them, used waste bins and wore personal protective wear when handling HCWs. A high proportion had satisfactory $\mathrm{HCW}$ management practices. Health workers in teenage corner, those who had attended training on HCW management and those who thought that HCW 
Table 3 Knowledge and attitudes of Health workers on HCW management

\begin{tabular}{|c|c|c|}
\hline Variables & $\begin{array}{l}\text { Frequency } \\
(n=200)\end{array}$ & $\begin{array}{l}\text { Percentage } \\
(\%)\end{array}$ \\
\hline \multicolumn{3}{|l|}{ Knowledge on HCW Management } \\
\hline \multicolumn{3}{|l|}{$\mathrm{HCW}$ management is } \\
\hline Activities and actions to manage waste from its inception to final & 190 & 95.0 \\
\hline Collection of waste from one central place & 03 & 1.5 \\
\hline Generation of waste & 07 & 3.5 \\
\hline \multicolumn{3}{|l|}{ Knowledge of risks of poor HCW management } \\
\hline Yes & 182 & 91.0 \\
\hline No & 18 & 9.0 \\
\hline \multicolumn{3}{|l|}{ Knowledge of the level of Risk to health workers } \\
\hline High & 182 & 91.0 \\
\hline Low & 18 & 9.0 \\
\hline \multicolumn{3}{|l|}{ Infections due to poor HCW management can be avoided } \\
\hline Yes & 179 & 89.5 \\
\hline No & 21 & 10.5 \\
\hline \multicolumn{3}{|l|}{ Ever attended training in $\mathrm{HCW}$ management } \\
\hline Yes & 120 & 60.0 \\
\hline No & 80 & 40.0 \\
\hline \multicolumn{3}{|l|}{ Number of Trainings attended $(n=120)$} \\
\hline $1-2$ & 79 & 65.8 \\
\hline 3 and above & 41 & 34.2 \\
\hline \multicolumn{3}{|c|}{ Knowledge of bin colour codes for different waste streams (waste segregation) } \\
\hline Know (Red, yellow, black) & 179 & 89.5 \\
\hline Do not know & 21 & 10.5 \\
\hline Knowledge scores (Cls for High Knowledge) & $(65.2-77.8)$ & \\
\hline Poor knowledge & 57 & 28.5 \\
\hline High Knowledge & 143 & 71.5 \\
\hline \multicolumn{3}{|l|}{ Attitudes on healthcare wastes management } \\
\hline \multicolumn{3}{|l|}{ HCW management is important } \\
\hline Yes & 181 & 90.5 \\
\hline No & 19 & 9.5 \\
\hline \multicolumn{3}{|l|}{ Strict implementation is necessary for proper HCW management } \\
\hline Yes & 186 & 93 \\
\hline No & 14 & 7.0 \\
\hline \multicolumn{3}{|l|}{ HCW management is a serious problem } \\
\hline Yes & 182 & 91.0 \\
\hline No & 18 & 9.0 \\
\hline
\end{tabular}

Cls: Confidence Intervals

management was a challenge had higher odds of having satisfactory HCW management practices.

Concerning Knowledge on HCW management, most health workers had high knowledge especially on waste segregation and level of risk to health posed by HCWs. Similar findings have been reported in other studies where most health workers were aware of the risk of hazards such as injuries, infections (HIV/AIDS, Hepatitis $\mathrm{B}$ and $\mathrm{C}$ ), and environmental pollution caused by improper HCW management $[32,33]$. The prior trainings on HCW management that most health workers had, partly explains the high knowledge. In our study, $60 \%$ of participants had prior trainings consistent with what has been reported in other studies which indicated 
Table 4 Practices of health workers on HCW management

\begin{tabular}{|c|c|c|}
\hline Variables & Frequency $(n=200)$ & Percentage (\%) \\
\hline \multicolumn{3}{|l|}{ Presence of litter/waste bins in work station ${ }^{\mathrm{b}}$} \\
\hline Yes & 188 & 94.0 \\
\hline No & 12 & 6.0 \\
\hline \multicolumn{3}{|l|}{ Waste bins colour coded ${ }^{2}$} \\
\hline Yes & 164 & 82.0 \\
\hline No & 36 & 18.0 \\
\hline \multicolumn{3}{|l|}{ Uses general pit to dispose general waste ${ }^{b}$} \\
\hline Yes & 71 & 35.5 \\
\hline No & 129 & 64.5 \\
\hline \multicolumn{3}{|l|}{ Health workers dispose pathological wastes in the placenta pit ${ }^{b}$} \\
\hline Yes & 163 & 81.5 \\
\hline No & 37 & 18.5 \\
\hline \multicolumn{3}{|l|}{ Presence of Expired drugs at the work station ${ }^{b}$} \\
\hline Yes & 97 & 48.5 \\
\hline No & 45 & 22.5 \\
\hline Did not know & 58 & 29.0 \\
\hline \multicolumn{3}{|l|}{ Disposal of expired drugs } \\
\hline Burning & 18 & 9.0 \\
\hline Waste bin company & 102 & 51.0 \\
\hline Return to national medical stores & 76 & 38.0 \\
\hline Did not know & 4 & 2.0 \\
\hline \multicolumn{3}{|l|}{ Use of Personal protective equipment (gloves, nose masks, clinical coats) ${ }^{b}$} \\
\hline Yes & 160 & 80.0 \\
\hline No & 40 & 20.0 \\
\hline \multicolumn{3}{|l|}{ Regularity of use of Personal protective equipment ${ }^{\mathrm{b}}$} \\
\hline Always & 144 & 72.0 \\
\hline Occasionally & 56 & 28.0 \\
\hline \multicolumn{3}{|l|}{ Ever been affected due to poor HCW management } \\
\hline Yes & 56 & 28.0 \\
\hline No & 144 & 72.0 \\
\hline \multicolumn{3}{|l|}{ Effects of poor HCW management $(n=56)$} \\
\hline Needle pricks & 39 & 69.6 \\
\hline Infection & 15 & 26.8 \\
\hline Spills of Blood & 02 & 3.8 \\
\hline \multicolumn{3}{|l|}{ Ever reported injury to infection and control Unit } \\
\hline Yes & 35 & 17.5 \\
\hline No & 165 & 82.5 \\
\hline Health care waste management status (Cls for satisfactory HCW management) & $(67.8-80.1 \%)$ & \\
\hline Satisfactory & 148 & 74.0 \\
\hline Unsatisfactory & 52 & 26.0 \\
\hline
\end{tabular}

${ }^{\mathrm{b} V a r i a b l e s ~ u s e d ~ i n ~ a s c e r t a i n i n g ~} \mathrm{HCW}$ management status

that most health workers had trained on HCW management. Training on HCW management is considered critical to success of any waste management programme; It improves knowledge of health workers, increases their cooperation with $\mathrm{HCW}$ programmes and also impacts on their practices on $\mathrm{HCW}$ management [34-36]. It is 
Table 5 Independent predictors of HCW management among health workers

\begin{tabular}{|c|c|c|c|c|c|}
\hline Variables & $\begin{array}{l}\text { Frequency } \\
(n=200)\end{array}$ & Proportion \% & Crude PR 95\% (Cl) & $\begin{array}{l}\text { Adjusted PR } \\
95 \% \mathrm{Cl}\end{array}$ & $P$ value \\
\hline \multicolumn{6}{|l|}{ Sex } \\
\hline Male & 53 & 26.5 & 1 & 1 & \\
\hline Female & 147 & 73.5 & $1.04(0.86-1.27)$ & $1.17(0.99-1.40)$ & 0.068 \\
\hline \multicolumn{6}{|l|}{ Age (Years) } \\
\hline $18-35$ & 131 & 65.5 & 1 & 1 & \\
\hline 35 and Above & 69 & 34.5 & $1.22(1.05-1.43)^{*}$ & $1.13(0.99-1.30)$ & 0.060 \\
\hline \multicolumn{6}{|l|}{ Marital status } \\
\hline Married & 135 & 67.5 & 1 & & \\
\hline Unmarried & 65 & 32.5 & $0.99(0.84-1.19)$ & & \\
\hline \multicolumn{6}{|l|}{ Religion } \\
\hline Christian & 161 & 80.5 & 1 & & \\
\hline Non-Christian & 39 & 19.5 & $0.84(0.65-1.08)$ & & \\
\hline \multicolumn{6}{|l|}{ Job designation } \\
\hline Nurse/midwife & 151 & 75.5 & 1 & & \\
\hline Medical officer & 16 & 8.0 & $0.83(0.56-1.22)$ & & \\
\hline Counsellor & 18 & 9.0 & $0.88(0.63-1.24)$ & & \\
\hline Others (laboratory personnel, social workers) & 15 & 7.5 & $1.06(0.81-1.38)$ & & \\
\hline \multicolumn{6}{|l|}{ Department } \\
\hline Outpatient department & 124 & 62.0 & 1 & 1 & \\
\hline Maternity ward & 39 & 19.5 & $0.79(0.61-1.04)$ & $0.83(0.66-1.03)$ & 0.092 \\
\hline HIV section & 10 & 5.0 & $0.52(0.24-1.11)$ & $0.55(0.26-1.15)$ & 0.111 \\
\hline Teenage Corner & 10 & 5.0 & $1.29(1.17-1.42)^{*}$ & $1.10(1.01-1.29)^{*}$ & 0.043 \\
\hline Other departments & 17 & 8.5 & $1.06(0.84-1.35)$ & $1.14(0.89-1.47)$ & 0.285 \\
\hline \multicolumn{6}{|l|}{ Level of education } \\
\hline Higher secondary & 34 & 17.0 & 1 & 1 & \\
\hline Diploma & 136 & 68 & $1.69(1.20-2.39)^{*}$ & $1.49(1.13-1.96)^{*}$ & 0.005 \\
\hline Lower secondary & 30 & 15.0 & $1.07(0.66-1.72)$ & $1.14(0.77-1.68)$ & 0.523 \\
\hline \multicolumn{6}{|l|}{ Knowledge of risks of poor HCW management } \\
\hline Did not know & 10 & 5.0 & 1 & & \\
\hline Know & 190 & 95.0 & $1.51(0.80-2.82)$ & & \\
\hline \multicolumn{6}{|l|}{ Knowledge of risk of HCW to health workers } \\
\hline High & 182 & 91.0 & 1 & 1 & \\
\hline Low & 18 & 9.0 & $1.73(1.03-2.92)^{*}$ & $1.09(0.67-1.79)$ & 0.717 \\
\hline \multicolumn{6}{|l|}{ Ever attended training in HCW management } \\
\hline No & 80 & 40.0 & 1 & 1 & \\
\hline Yes & 120 & 60.0 & $1.30(1.08-1.58)^{*}$ & $1.19(1.01-1.42)^{*}$ & 0.042 \\
\hline \multicolumn{6}{|l|}{ Knowledge of colour codes } \\
\hline Did not know & 21 & 10.5 & 1 & & \\
\hline Know & 179 & 89.5 & $1.12(0.82-1.54)$ & & \\
\hline \multicolumn{6}{|l|}{ Overall Knowledge ${ }^{c}$} \\
\hline Low & 57 & 28.5 & 1 & & \\
\hline High & 143 & 71.5 & $3.77(1.92-7.39)$ & & \\
\hline
\end{tabular}

HCW management important 
Table 5 Independent predictors of HCW management among health workers (Continued)

\begin{tabular}{|c|c|c|c|c|c|}
\hline Variables & $\begin{array}{l}\text { Frequency } \\
(n=200)\end{array}$ & Proportion \% & Crude PR 95\% (Cl) & $\begin{array}{l}\text { Adjusted PR } \\
95 \% \mathrm{Cl}\end{array}$ & $P$ value \\
\hline No & 19 & 9.5 & 1 & 1 & \\
\hline Yes & 181 & 90.5 & $3.78(1.57-9.07)^{*}$ & $2.81(1.22-6.47)^{*}$ & 0.016 \\
\hline \multicolumn{6}{|c|}{ HCW management a serious problem } \\
\hline Not serious & 18 & 9.0 & 1 & & \\
\hline Very serious & 182 & 91.0 & $1.36(0.89-2.08)$ & & \\
\hline \multicolumn{6}{|c|}{ Ever been affected by HCW } \\
\hline No & 144 & 72.0 & 1. & & \\
\hline Yes & 56 & 28.0 & $0.99(0.82-1.19)$ & & \\
\hline \multicolumn{6}{|c|}{ Ever reported injury to infection and control Unit } \\
\hline No & 165 & 82.5 & 1 & & \\
\hline Yes & 35 & 17.5 & $1.05(0.86-1.29)$ & & \\
\hline
\end{tabular}

$P R$ Prevalence ratios, $C$ l Confidence Interval, ${ }^{*} p<0.05$

${ }^{c}$ Not included in multivariable model due to collinearity

therefore important to intensify training for all health workers with emphasis on implications of proper HCW management on costs and risks to human and environmental health. Most health worker believed that strict enforcement is essential for proper HCW management. Many scholars have recommended strict enforcement; adding that this has to be complemented with continuous trainings [37, 38].

Wearing personal protective equipment (PPE) such as gloves, masks, clinical coats, shoes helps to minimise exposure to infections and injuries [39]. In this study, most health workers wore appropriate (PPE) which is a good practice since it minimises risk of contact with the waste. Our findings did not corroborate with findings of a cross sectional study conducted in a Tanzanian Municipality in which most health workers did not wear appropriate personal protective gear [40]. The low usage in the aforementioned study was attributed to the fact that health workers were not provided with protective gear by their employees. It is appropriate to ensure adequate provision of PPE and then supervision for proper and consistent use.

Generally, the practices of health workers on HCW management were satisfactory which relates to appreciable knowledge as there was significant association between practice and knowledge scores $(p<0001)$. The satisfactory practices suggest that health workers might be less likely to experience adverse effects associated with poor handling. Our finding corroborates with findings of a similar study conducted in Egypt in which most health workers had satisfactory practice scores [41]. It was found that health workers with diploma education were more likely to have satisfactory $\mathrm{HCW}$ management practices as compared to those with higher secondary education, a finding which is understandable given that a diploma generally offers better opportunity to acquire extensive knowledge on HCW management and yet such opportunity is almost non-existent in secondary school. Continued professional development may help improve the practices of health workers on management of HCWs.

Health workers who had received training on HCW management were more likely to have satisfactory practices. A possible explanation may be because they are able to put into practice what they have trained in. Our findings also support the findings of a similar study in Ethiopia which revealed that health workers trained on healthcare waste management were more likely to exhibit satisfactory practices on HCW management [42]. Trainings should therefore be intensified as they have shown to improve practices of health workers regarding how they handle HCW.

Health workers who thought that HCW management was important were more likely to have satisfactory $\mathrm{HCW}$ management practices as compared to those who thought otherwise. This finding is understandable because it is expected that such health workers based on their attitude would take practical measures to properly handle HCWs. It has been shown that health workers are more likely to be cautious and take necessary measures when they realise that $\mathrm{HCW}$ poses risk [42]. Health workers in the teenage corner were more likely to have satisfactory $\mathrm{HCW}$ management practices as compared to those in the outpatient clinic. This is understandable because further analysis found that all health workers in the teenage corner had diploma education unlike in the Outpatient department. The fact that higher education levels were associated with satisfactory practices may have modified the association between department and HCW management.

\section{Limitations}

This study had some limitations; firstly, the sample size was relatively small which limits the generalizability of 
the results. The second limitation is that some variables that would have improved the assessment of Knowledge and attitudes even further were missed in the design of the tool. Future studies should consider other variables including those in the $\mathrm{WHO}$ checklists on medical waste management. Notwithstanding the limitations, the study provides useful information about management of HCWs among health workers and associated factors in primary health care facilities in Kampala, Uganda.

\section{Conclusions}

Health workers in primary health care facilities in Kampala, Uganda generally have satisfactory practices on $\mathrm{HCW}$ management. Health workers with at least diploma education and those trained on HCW management were more likely to have satisfactory $\mathrm{HCW}$ management practices. Refresher trainings on $\mathrm{HCW}$ management and continuous supervision are therefore important in promoting proper $\mathrm{HCW}$ practices among health workers.

\section{Abbreviations \\ HCW: Health Care Waste; HIV: Human Immunodeficiency Virus; IHSU: International Health Sciences University; KCCA: Kampala Capital City Authority; PPE : Personal protective Equipment; PRs: Prevalence Ratios; WHO: World Health Organization}

\section{Acknowledgements}

The authors appreciate all the staff of the health facilities surveyed and the local authorities for their immense support during the study.

\section{Funding}

No funding was received to produce this manuscript.

\section{Availability of data and materials}

The dataset used to support the findings of the current study is available from the corresponding author on reasonable request.

\section{Authors' contributions \\ JM and STW designed the study and collected the data. STW and FO carried out the analysis and wrote the first draft of the paper. STW spearheaded the writing of the first draft. FO participated in scientific and technical editing of the manuscript to ensure appropriate intellectual content. All authors were involved in the writing, critical review and approval of the final version of the manuscript.}

\section{Ethics approval and consent to participate}

Approval to conduct this study was obtained from International Health Sciences University (IHSU) Research Ethics Committee, in Kampala. Administrative clearance was also obtained from Kampala Capital City Authority (KCCA) and the In-Charges of the health facilities. The study details were explained to the individual participants; participation in this study was voluntary and all consenting health workers signed a written informed consent form.

\section{Consent for publication}

Not applicable

\section{Competing interests}

The authors declare that they have no competing interests.

\section{Publisher's Note}

Springer Nature remains neutral with regard to jurisdictional claims in published maps and institutional affiliations.

\section{Author details}

'Department of Disease Control and Environmental Health, School of Public Health, Makerere University, P.o Box 7072, Kampala, Uganda. ${ }^{2}$ International Health Sciences University (IHSU), Kampala, Uganda.

Received: 24 October 2018 Accepted: 11 February 2019

Published online: 18 February 2019

\section{References}

1. Arab M, Baghbani RA, Tajvar M, Pourreza A, Omrani G, Mahmoudi M. The assessment of hospital waste management:a case study in Tehran. Waste Manag Res. 2008;26(3):304-8

2. Rodriquez-Morales AJ. Current topics in public health. Rijeka: InTech; 2013.

3. Pépin J, Abou Chakra CN, Pépin E, Nault V, Valiquette L. Evolution of the global burden of viral infections from unsafe medical injections, 2000-2010. PLoSOne. 2014;9(6):e99677.

4. Johannessen LM, Dijkman M, Bartone C, Hanrahan D, Boyer MG, Chandra C Health care waste management guidance note. Washington DC: World Bank. In; 2000

5. Manyele SV. Effects of improper hospital-waste management on occupational health and safety. Afr Newsl Occup Health Safety. 2004;14(2):30-3.

6. World Health Organization (WHO). Health-care waste [https://www.who.int/ en/news-room/fact-sheets/detail/health-care-waste].

7. Askarian $\mathrm{M}$, Heidarpoor $\mathrm{P}$, Assadian $\mathrm{O}$. A total quality management approach to healthcare waste management in Namazi hospital, Iran. Waste Manag. 2010;30(11):2321-6.

8. Akter N: Medical Waste Manag: a review. Bangkok: Environmental Engineering Program, School of Environment, Resources and Development. Asian Institute of Technology, Thailand. 2000.

9. Patwary MA, Harare TW, Sarker MH. Assessment of occupational and environmental safety associated with medical waste disposal in developing countries. A qualitative approach. Saf Sci. 2011:49:8-9.

10. Coker A, Sangodoyin A, Sridhar M, Booth C, Olomolaiye P, Hammond F. Medical waste management in Ibadan, Nigeria: obstacles and prospects. Waste Manag. 2009;29(2):804-11.

11. Harhay MO, Halpern SD, Harhay JS, Olliaro PL: Health care waste management: a neglected and growing public health problem worldwide 2009, 14(11):1414-1417.

12. Diaz LF, Eggerth LL, Enkhtsetse SH, Savage GM. Characteristics of healthcare. Waste Manag Res. 2008:28:1219-26.

13. Bdour A, Altrabsheh B, Hadadin N, Al-Shareif M. Assessment of medical wastes management practice: a case study of the northern part of Jordan. Waste Manag. 2007;27(6):746-59

14. Hassan MM, Ahmed SA, Rahman KA, Biswas TK. Pattern of medical waste management: existing scenario in Dhaka City, Bangladesh. BMC Public Health. 2008;8:36.

15. Patil GV, Parokhrel K. Biomedical solid waste management in an Indian hospital. Waste Manag. 2005;25:592-9

16. Nkonge Njagi A, Mayabi Oloo A, Kithinii J, Magambo Kithinji J. Knowledge, attitude and practice of health-care waste management and associated health risks in the two teaching and referral hospitals in Kenya. J Community Health. 2012;37(6):1172-7.

17. Makhura RR, Matlala SF, Kekana MP. Medical waste disposal at a hospital in Mpumalanga Province, South Africa: implications for training of healthcare professionals. S Afr Med J. 2016;106(11):1096-102.

18. Muluken A, Haimanot G, Mesafint M. Healthcare waste management practices among healthcare workers in healthcare facilities of Gondar town, Northwest Ethiopia; 2014.

19. AIDSTAR-One: Fact sheet: Health care Waste Manag in Uganda. In.; 2000

20. Victoria M, Pearson J, Michael K, Namisango E, Rogers-Bloch Q, Amandua J. Assessment of Health Care Waste Management Practices in Three Districts in Uganda. Arlington, VA: USAID's AIDS Support and Technical Assistance Resources, AIDSTAR-One, Task Order One; 2014.

21. Ruoyan G, Lingzhong X, Huijuan L, Chengchao Z, Jiangjiang H, Yoshihisa S, Wei T, Chushi K. Investigation of health care waste management in Binzhou District, China. Waste Manag. 2010;30(2):246-50.

22. $\mathrm{MOH}$ : Environmental and social impact assessment for proposed renovation and equipping health facilities in Uganda. In.; 2010. 
23. Mugambe RK, Ssempebwa JC, Tumwesigye NM, Bas W, Adebola A. Healthcare waste management in Uganda: management and generation rates in public and private hospitals in Kampala. J Public Health. 2012;20(3):245-51.

24. Manyele S, Anicetus H. Management of medical waste in Tanzania hospitals. Tanzan J Health Research. 2006;8(3).

25. UBOS. National population and housing census 2014 provisional results, Uganda Bureau of Statistics. Kampala: Ministry of planning and regional development; 2014.

26. Wiegand H, Kish L, Sampling S. John Wiley \& sons, Inc., New York, London 1965, IX + 643 S., 31 Abb., 56 tab., Preis 83 s. Biom Z. 1968;10(1):88-9.

27. Njue PM, Cheboi KS, Shadrak O. Adherence to healthcare waste management guidelines among nurses and waste handlers in Thika subcounty- Kenya. Ethiopian J Health Sci. 2015;25(4):295-304.

28. Allen M. The SAGE encyclopedia of communication research methods; 2017

29. Andrade C. Understanding relative risk, odds ratio, and related terms: as simple as it can get. J Clin Psychiatry. 2015;76(7):e857-61.

30. Schmidt CO, Kohlmann T. When to use the odds ratio or the relative risk? Int J Public Health. 2008;53(3):165-7.

31. Elm Ev ADG, Egger M, Pocock SJ, Gøtzsche PC, Vandenbroucke JP Strengthening the reporting of observational studies in epidemiology (STROBE) statement: guidelines for reporting. Observational Stud. 2007; 335(7624):806-8

32. Saraf Y, Shinde M, and Tiwari SC. Study of awareness status about hospital waste management among personnel and quantification. Indian J Community Med. 2006:31(2):111.

33. Pandit NB, Mehta HK, Kartha GP, Choudhary SK. Management of biomedical waste: awareness and practices in a district of Gujarat. Indian J Public Health. 2005;49(4):245-7.

34. Kumar R, Samrongthong R, Shaikh BT. Knowledge, attitude and practices of health staff regarding infectious waste handling of tertiary care health facilities at metropolitan city of Pakistan. J Ayub Med Coll Abbottabad. 2013; 25(1-2):109-12.

35. Kumar R, Somrongthong R, Shaikh BT. Effectiveness of intensive healthcare waste management training model among health professionals at teaching hospitals of Pakistan: a quasi-experimental study. BMC Health Serv Res. 2015;15:81.

36. Al-Khatib IA. Problems of management of medical solid waste at primary health care centres in the Palestinian territory and their remedial measures. East Mediterr Health J. 2014;19(Suppl 3):S152-8.

37. Rajan R, Robin DT, Vandanarani M. biomedical waste management in Ayurveda hospitals - current practices \& future prospectives. J Ayurveda Integr Med 2018. http://dx.doi.org/10.1016/j.jaim.2017.07.011.

38. Bansal M, Mishra A, Gautam P, Changulani R, Srivastava D, Gour N Biomedical waste management: awareness and practices in a district of Madhya Pradesh. Natl J Commun Med. 2011;2(3).

39. Askarian M, Vakili M, Kabir G. Results of a hospital waste survey in private hospitals in Fars province, Iran. Waste Manag. 2004;24:347-52.

40. Kuchibanda K, Mayo AW. Public health risks from mismanagement of healthcare wastes in Shinyanga municipality health facilities, Tanzania. Scientific World J. 2015;2015:981756.

41. Hakim SA, Mohsen A, Bakr I. Knowledge, attitudes and practices of healthcare personnel towards waste disposal management at Ain Shams University hospitals, Cairo. East Mediterr Health J. 2014;20(5):347-54.

42. Muluken AY, Haimanot GM, Woldeyohannes SM. A cross sectional study on factors associated with risk perception of healthcare workers toward healthcare waste management in health care facilities of Gondar town, Northwest Ethiopia. Int J Infect Control. 2012;8(3).

\section{Ready to submit your research? Choose BMC and benefit from:}

- fast, convenient online submission

- thorough peer review by experienced researchers in your field

- rapid publication on acceptance

- support for research data, including large and complex data types

- gold Open Access which fosters wider collaboration and increased citations

- maximum visibility for your research: over $100 \mathrm{M}$ website views per year

At $\mathrm{BMC}$, research is always in progress.

Learn more biomedcentral.com/submissions 